\title{
PIETER BRUEGHEL. TRIUNFO DE LA MUERTE
}

\author{
Jesús María González de Zárate \\ Universidad del País Vasco
}

Aeterne pungit, cito volat et occidit

Eternamente hiere, vuela veloz y mata

RESUMEN: El Triunfo de la Muerte en pintura de Brueghel nos Ileva a considerar algunos detalles que se dan cita y que explican el sentido final de la composición. Tratamos de ahondar en el lenguaje común entre los artistas del Humanismo por el que establecían un claro sentido semántico a través de sus formas. Así, los Hieroglyphica se convierten en fuente singular a la hora de considerar los presupuestos iconográficos que establecen una concreta lectura de la obra pictórica. Con ello, nuestro propósito es doble en el comentario: por un lado establecer la "historia que encierra la pintura"; por otro, "historiar la propia imagen" en sus detalles.

Palabras clave: Iconografía, Hieroglyphica, Brueghel, máscara, búho.

\section{PIETER BRUEGHEL. TRIONFO DELLA MORTE}

SOMMARIO: II "Trionfo della morte", dipinto da Bruegel, ci porta a considerare alcuni dettagli che si incontrano sulla tela e che spiegano il senso compiuto della composizione. Ora, cerchiamo di approfondire il linguaggio comune tra gli artisti dell'Umanesimo, per il quale stabilirono un chiaro senso semantico attraverso le loro forme. Così, gli Hieroglyphica si trasformano in fonti singolari nel momento in cui andiamo a considerare i presupposti iconografici che stabiliscono, a loro volta, una concreta lettura dell'opera pittorica. E' per questo motivo che il nostro proposito si divide in due parti: da un lato intendiamo stabilire la "storia che racchiude la pittura", dall'altro cerchiamo di "istoriare" la propria immagine nei suoi dettagli.

Parole chiave: Iconografía, Hieroglyphica, Brueghel, maschera, gufo. 
En los albores del Renacimiento, hacia 1436, León Battista Alberti, en su tratado della Pittura, repara en un aspecto muy singular para la Historia del Arte: llegar al sentido final que el artista ha querido conferir a su creación. El tratadista considera el propósito fundamental de la pintura que poco dista del que, en su tiempo, propuso Filostrato. Nos dice en su libro III:

También debe leer con atención las obras de los Poetas y Retóricos, pues los ornatos de ellas tienen mucha conexión con los de la Pintura: además le dará muchas luces, y le servirá de no poco auxilio para inventar y componer una historia la conversación de los hombres literatos y abundantes de noticias, pues es evidente que el principal mérito consiste en la invención, la cual tiene la virtud de agradar y deleitar por si sola sin el auxilio de la Pintura.

Y siendo la principal obra de un Pintor la historia, en donde se ha de encontrar la abundancia y la excelencia de todas las cosas, es preciso absolutamente saber pintar con perfección de todo, en cuanto alcance el entendimiento, no solo la figura humana, sino la de todos los animales, y demás objetos que percibe la vista y son dignos de mirarse, para que nadie eche de menos en un cuadro aquella variedad y abundancia, sin la cual ninguna obra tiene estimación.

La invención, la historia que se presenta, nutrida de Poetas y Retóricos, da como resultado una pintura intelectual que se hace preciso analizar en sus detaIles. Por ello, si bien Alberti en su tratado de pintura puntualizaba que lo más importante en las artes son los asuntos, las historias que se presentan, es nuestro interés discurrir no solamente en los asuntos, también por la propia historia que la imagen contiene en sus detalles, analizando sus precedentes tanto visuales como literarios. En consecuencia, trataremos de "historiar la forma". En este aspecto se centra la Iconografía que es lo mismo que decir la Historia del Arte pues, como Historia, no deja de ser y explicar el tiempo, por tanto y esencialmente por esta disciplina entendemos el discurso del Arte, el discurrir de la Imagen, a modo de documento, en el tiempo. Así, tratar de sus precedentes establece lo que específicamente entendemos por la Historia del Arte, ciencia que se aleja de otros planteamientos formales objetivamente tratados por aqueIlos especialistas conocedores de técnicas, tratamientos y comportamientos de las Bellas Artes ya catalogadas por Charles Batteux desde el siglo XVIII.

En consecuencia, explicar la historia que presenta el artista en su creación, introducirnos en sus detalles a modo de una sintaxis que se encuentra en función de un todo e "historiar" las formas en el discurso del tiempo supone el centro de nuestra metodología. Por tanto, en estos aspectos centraremos el presente comentario a la creación de un singular artista pintor, Pieter Brueghel el viejo.

El Museo del Prado custodia una singular pintura de Pieter Brueghel Ilamado "el viejo" (1525-1599), se trata del argumento conocido como el Triunfo de la Muerte (c.1562) (Lám. 1a). Algunos detalles de la pintura tuvimos ocasión de 
Lámina 1a. Pieter Brueghel. Triunfo de la

Muerte (Museo del

Prado) (c. 1562).

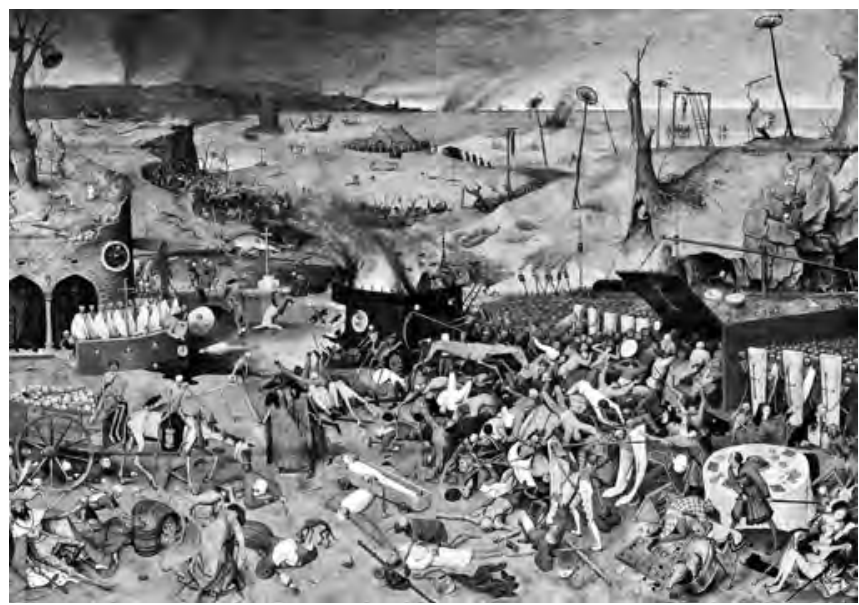

exponer y publicar en el citado Museo dentro del ciclo anual de conferencias titulado "Los dioses cautivos", donde participamos con el tema: "De algunas pinturas en el Museo del Prado. Mitos en metáforas" ${ }^{\prime 1}$.

Poco se conoce sobre la biografía del pintor holandés, una fuente inexcusable proviene del Ilamado "Vasari flamenco", Karel van Mander quien, como el italiano, se ocupó de relacionar una pequeña biografía de los maestros del arte flamenco, editando el año 1604 sus biografías de pintores (Le livre des peintres. Schilder-boeck). Sobre Brueghel nos dice:

Nacido cerca de Breda en el pueblo cuyo nombre tomó para transmitirlo a sus descendientes, Pieter Brueghel fue el primer discípulo de Pieter Coeck de quien se casa más adelante con la hija que le había Ilevado en sus brazos cuando ella era una niña.

Luego colaboró con Jerónimo Cock, entonces fue a Francia e Italia. Las obras de Jerónimo Bosco había sido el objeto especial de sus estudios y, a su vez, hizo un montón de diabluras y temas cómicos, por lo que le llamaron Pedro el Gracioso. De hecho, hay pocas obras de su mano que podamos mirar sin reír y el espectador más sombrío se hace menos severo

1. GONZÁLEZ DE ZÁRATE, J.M., "De algunas pinturas en el Museo del Prado. Mitos en Metáforas". En Los Dioses Cautivos (Museo del Prado Madrid 2011). Sobre la procedencia de la pintura se dice en el comentario técnico del Museo: Colección Real (Adquirida por la reina Isabel Farnesio entre 1746-1759, entre las pinturas incorporadas a La Granja tras la realización del inventario de 1746 y la partida de la Reina a Madrid en 1759); colección Isabel Farnesio, Palacio Real de La Granja de San Ildefonso (Segovia), Cuarto bajo-pieza segunda inmediata a la galería, 1766, [s. n.]; La Granja, 1774; La Granja, 1794, [s. n.]; ingresó en el Museo del Prado, procedente de La Granja, en 1827. 
ante él. Brueghel, durante sus viajes, hizo un considerable número de vistas tomadas de la naturaleza, de modo que podríamos decir que al atravesar los Alpes, se había tragado las montañas y las rocas para vomitarlas, a su vez, sobre telas y tablas, tanto logró representar la naturaleza con fidelidad. Se estableció en Amberes y entró en el gremio en 1551. Un comerciante Ilamado Hans Franckert, le encomendó muchas pinturas. Era un buen hombre que estaba muy apegado al pintor.

El comentario de van Mander nos ofrece varios aspectos singulares en el pintor. Precisa que fue el primero entre toda una dinastía de artistas, los Brueghel: su hijo Pieter el joven (1564-1638), otro de sus hijos conocido como Jan Brueghel "el viejo" (1568-1625), su nieto Jan Brueghel "el joven" (1601-1678) y el bisnieto Abraham Brueghel (1631-1719). De igual manera nos señala que colaboró con el editor de estampas Jerónimo Cock, así lo hizo en su taller conocido como Aux Quatre Vents hacia 1555 incorporando una tendencia al género popular distante a la del italiano Giorgio Ghisi quien permaneció junto a Cock hasta la fecha señalada. Pieter ofreció en este momento singulares dibujos que fueron estampados por importantes maestros calcográficos. Nos habla van Mander de los argumentos "graciosos", es decir, de los temas que responden a caprichos personales conocidos en esa época como "drolerías", imágenes arbitrarias o fantásticas de las que, como es sabido, fue fiel exponente Jerónimo Bosco. También relaciona al artista con el taller de Pieter Coeck y nos dice que casó con su hija. Esto explica sin duda la tendencia de Brueghel hacia las "drolerías" que difundiera el Bosco y que amanecen nuevamente en la pintura de nuestro artista, así lo comprobamos en sus dibujos para la serie sobre los pecados capitales y en sus composiciones, como recoge Boon, sobre la Caída de los ángeles rebeldes (1562. Musee d'Art Ancien. Musees Royaux des Beaux-Arts) y la maga Mad Meg (1562. Museum Mayer van den Bergh), sin olvidar la pintura que nos ocupa, curiosamente elaborada en la misma fecha, el Triunfo de la Muerte ${ }^{2}$.

Algunas copias se conservan de esta pintura en óleo sobre tabla como la custodiada en el Landesmuseum Joanneum de Graz y otras atribuidas a su hijo Jan. La obra fue citada en la edición señalada de van Mander y perteneció a la colección Philipps van Valkenisse de Amberes con anterioridad a que se inventariara en el palacio de la Granja en 1774.

El tema que centra nuestro comentario, el Triunfo de la Muerte y la fugacidad de la vida, se hace general en la edad del Humanismo, principalmente en la Europa del norte, y se extenderá por el Ilamado Barroco mediante las conocidas vanitas. Así, el también citado pintor y suegro de nuestro artista, Pieter Coecke van Aelst, lo recrea en varias de sus composiciones.

2. Sobre la biografía de Brueghel y su relación con la estampa ver: GONZÁLEZ DE ZÁRATE, J.M., Artistas Grabadores en la Edad del Humanismo. Pamplona 2000. 
Las conocidas danzas de la muerte como las de Holbein, informaban sobre el sentido igualador de la muerte para todo estamento social, daban cuenta de su presencia siempre imprevista en el medio humano, aspectos para nada extraños en la pintura que analizamos. En este sentido, en inventario del siglo XIX se dice sobre la tabla que vamos a comentar:

En primer término está simbolizada la miseria de las grandezas humanas y lo perecedero de los mundanos placeres, un rey cae en tierra envuelto en su púrpura al mostrarle la muerte su última hora, y se ve despojado de sus riquezas. Varios jóvenes de ambos sexos ven interrumpido su banquete, sus juegos y sus goces y se resisten en vano a morir.

Es así que el óleo custodiado en el Museo del Prado es un discurrir sobre la presencia de la muerte. En él, se da cita todo un ejército de esqueletos que van poniendo fin a la vida en sus diferentes comportamientos y estamentos sociales. Su presencia se hace patente a la hilandera, al príncipe, a los divertidos jóvenes que juegan con las cartas y a los amantes que, entretenidos con la música, parecen ignorar su presencia.

Un tosco carro de madera recoge los cráneos, sobre ellos reposa una pala; el escuálido caballo se acompaña de un transido que, en sus manos, porta la campana anunciadora de su llegada y una lámpara; sobre su lomo un singular detalle, el cuervo (Lám. 1b). La idea se presenta clara, se trata

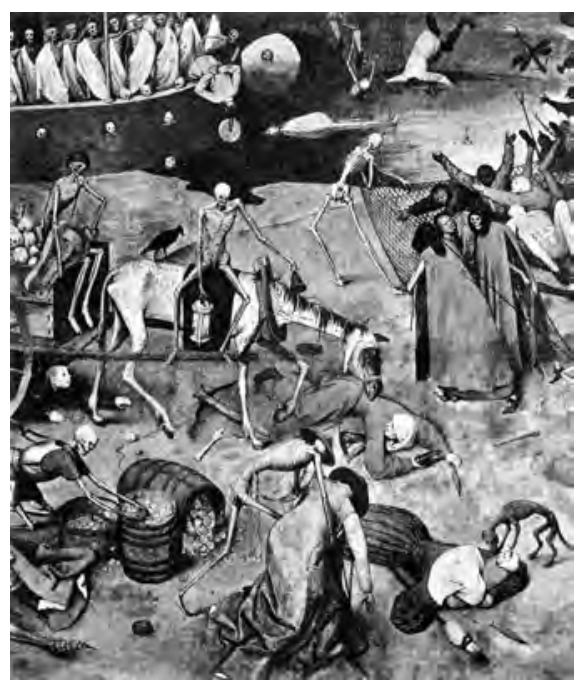

Lámina 1b. Pieter Brueghel. Triunfo de la Muerte. Carro de la Muerte (detalle). del anuncio de su imprevista presencia como se recoge en diferentes composiciones pictóricas en toda Europa. La imagen recuerda el relato sobre la apertura del cuarto sello en el libro del Apocalipsis (VI, 7-8) donde se dice:

Y cuando Él abrió el cuarto sello, oí la voz del cuarto animal, que decía: Ven y ve.

Y miré, y he aquí un caballo amarillo: y el que estaba sentado tenía por nombre Muerte; y el infierno le seguía: y le fue dada potestad sobre la cuarta parte de la tierra, para matar con espada, con hambre, con mortandad, y con las bestias de la tierra.

Se trata de uno de los jinetes del Apocalipsis que acompaña a la peste, la guerra y el hambre y que con tanta profusión quedó representando en las Biblias ilustradas de la época. 
El sentido apocalíptico parece continuar en otras recreaciones de la pintura, incluso en su aspecto lumínico de tonos muy apagados. Tres son los esqueletos trompeteros que nos presenta Brueghel en la tabla y que se corresponde con los tres ángeles anunciadores en la Revelación (VIII, 12-13):

Y el cuarto ángel tocó la trompeta, y fue herida la tercera parte del sol, y la tercera parte de la luna, y la tercera parte de las estrellas; de tal manera que se oscureció la tercera parte de ellos, y no alumbraba la tercera parte del día, y lo mismo de la noche.

Y miré, y oí un ángel volar por medio del cielo, diciendo en alta voz: ¡Ay! ¡ay! jay! de los que moran en la tierra, por razón de las otras voces de trompeta de los tres ángeles que han de tocar!

Vamos a detenernos en algunos detalles de la pintura que Pieter Brueghel compuso considerando sus precedentes tanto gráficos como literarios, para ello nuestro comentario quiere hacer presente las fuentes semánticas que, en la edad del Humanismo, fueron un recurso insoslayable para los grandes genios del arte. Me refiero a los Ilamados Hieroglyphica que ahora señalaremos y que se dieron a conocer en diferentes países e idiomas en el siglo XVI. Su difusión fue singular pues se publicaron en griego, en latín, italiano y francés, entre otras lenguas. La obra se universalizó bajo el título Los Hieroglyphica de Horapolo del Nilo que Filipo tradujo al griego.

Este pequeño texto en griego, atribuido a Horapolo, supone el único tratado de la antigüedad que tuvo como objeto la escritura egipcia y que ha llegado a nuestros días. En el tratado, la escritura es considerada en clave de ideograma como fue general en todos sus comentaristas hasta los estudios de Champollion en el siglo XIX. Fueron los neoplatónicos del siglo XV y XVI quienes extendieron la creencia del mito griego fundamentado en el simbolismo de los jeroglíficos egipcios.

Así, el Horapolo y otros continuadores del siglo XVI como Valeriano, establecieron las claves interpretativas de aquella cultura ancestral y oscura, sabia por excelencia, como lo fue la egipcia. Al igual que en los Emblemas, los Hieroglyphica presentan múltiples argumentos como son los dioses paganos, los elementos de la naturaleza, artilugios humanos, etc. Todo ello sujeto a una visión moral, alegórica y profunda, muy propia de un sentido trascendente que definió la cultura del Humanismo.

En este tiempo se consideró a Hermes Trismegisto como el inventor de la escritura, figura contemporánea a Moisés y que de igual manera vivió en Egipto donde enseñó su ciencia en una dimensión hermética. En estas mismas fechas se proponía la existencia de Horapolo. Hoy, gracias a la Suda, enciclopedia-diccionario del siglo $X$ escrita en griego, sabemos que esta figura y sus Hieroglyphica pertenecen al siglo $\mathrm{V}$ de nuestra era. 
El geógrafo Cristóforo Buondelmonti localizó el pequeño manuscrito de los Hieroglyphica en la isla de Andros hacia el año 1419 con unas 189 descripciones de figuras y sus interpretaciones. Su llegada a Florencia en el año 1421 estableció toda una revolución cultual entre los Humanistas quienes desde Plinio, sabían de la sabiduría y filosofía contenida en los obeliscos. Así, el célebre manuscrito, ignorado en su contenido por Buondelmonti, pasó a las manos de Poggio Bracciolini (traductor de Diodoro Sículo) y de Niccolò de' Niccoli, erudito y coleccionista muy interesado por las cuestiones egipcias. La difusión a partir de la fecha fue singular en el viejo continente destacando las ediciones latinas elaboradas en Italia y Francia en el siglo XVI. Los jeroglíficos se consideraban, en consecuencia, un medio, un recurso intelectual para conocer y desvelar en imágenes aquellos contenidos abstractos que conforman la vida humana.

El lenguaje, visual y semántico, influyó notablemente entre los artistas de los siglos XV al XVIII. Sus imágenes parlantes se fundamentaban en estos textos considerados ideogramas que, en realidad, suponían -como descubrió Champollion- un claro sistema fonético de escritura. Pero, en la época, se entendió como una poesía visual que los artistas consideraron como un novedoso e intelectual lenguaje, aunque hoy sabemos que, en realidad, no fue otra cosa sino una falacia, un argumento que dio como válido y científico pero que no lo fue en absoluto. Eso sí, en su tiempo todo un descubrimiento, un claro lenguaje, no menos real, para escritores y artistas.

En estos jeroglíficos encontramos, proponemos y fundamentamos una lectura de los detalles que componen la pintura de Pieter Brueghel. Es así que el citado cuervo sobre le escuálido caballo remite al contenido que nos ofrece la tabla, la muerte imprevista como se da cuenta en los citados Hieroglyphica de Horapolo3 (Lám. 1c). Leemos:

Un cuervo nocturno representa muerte que se acerca de repente a los polluelos de las cornejas por la noche, como la muerte se acerca de pronto.

Se ha de precisar que el ave, el señalado como cuervo nocturno, responde al búho como se desprende de las Historias de Animales de Aristóteles, Plinio, Ovidio y Eliano, identidad que se continúa en san Isidoro señalando que es ave propia de cementerios y, en similares términos, la propone Valeriano Bolzani en su también conocida Hieroglyphica editada a fines del siglo $\mathrm{XVI}^{4}$.

Variados son los ejemplos en pintura y la estampa que nos recrean el ave (cuervo-búho) con este sentido semántico. Brueghel, como lo apreciamos en

3. GONZÁLEZ DE ZÁRATE, J.M., Los Hieroglyphica de Horapolo. Madrid, 1991, p. 347.

4. GONZÁLEZ DE ZÁRATE, J.M., Los Hieroglyphica de Horapolo. Se señalan las fuentes clásicas que hacen corresponder al cuervo nocturno con la lechuza o el búho, es el caso de Aristóteles y Eliano. 

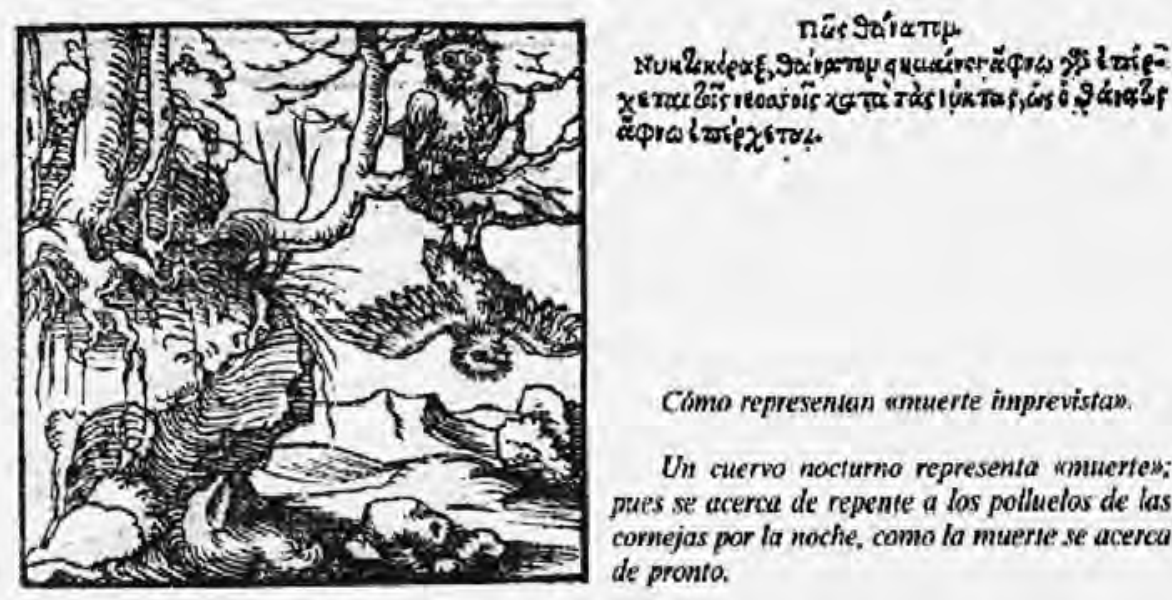

Como represendan ontuerte inprevistan.

Un cuervo nocturno representa imuertes: pues se acerce de repente a los polluelos de las connejas por la noche, como la muerse se acerca de pronto.

Lámina 1c. Horapolo. Hieroglyphica. Cuervo Nocturno.

Mantegna y su Oración en el Huerto, toma la fuente en el sentido literal y dispone un cuervo, la imagen del búho la apreciamos en diferentes composiciones que señalamos ${ }^{5}$ (Lám. 1d).

El cuervo nocturno, el búho, lo apreciamos con esta significación en la literatura emblemática, un género que, como es conocido, se inició con la edición del Emblematum liber de Andrés Alciato en el año 1531 y que tuvo un especial desarrollo en la Europa de los siglos XVI al XVIII. El emblema lo podemos considerar heredero de los señalados Hieroglyphica ya que presenta, en lo esencial, la misma intencionalidad doctrinal en base a la imagen y el texto, en consecuencia, una literatura visual y semántica.

5. Mantegna en su Oración en el Huerto de 1489 recrea al cuervo que reposa sobre un árbol anunciando el prendimiento que llevará a la posterior e inmediata muerte de Cristo. Los ejemplos en la pintura se manifiestan en singulares artistas como en Pietro di Giovanni d'Ambrogio quien hacia 1445 compone su Adoración de los Pastores, aquí el búho se dispone en el centro de escena explicando un destino, la muerte no anunciada del Redentor. En el Bosco y su Carro de heno, tabla compuesta hacia 1500, observamos el búho en la rama de un árbol junto a jóvenes en fiesta, el ave anuncia un final inesperado, también en su Ecce-Homo de hacia 1475 donde vemos el ave sobre Pilato como anuncio de una muerte segura e imprevista pues el gobernador romano, siguiendo los apócrifos, prometió a Prócula, su mujer, no condenarlo a muerte. También en el pintor Juan de Flandes y su Natividad de 1508 ocupando el centro de la composición en referencia a la futura muerte de Cristo desconocida para su madre María. En el artista alemán Hans Baldung Grien y su argumento sobre las Tres edades y la Muerte elaborado entre los años 1541-1544 que nos presenta a la muerte acompañada de su reloj de arena y con una lanza rota como anuncio de que la vida se acaba sin aviso alguno a cualquier edad; toma por su brazo a una anciana que arrastra consigo a una joven. En el suelo se dispone un niño, quizá muerto, y el señalado búho que vamos comentando. 
Lámina 1d. Andrea Mantegna. Oración en el Huerto (National Gallery. Londres).

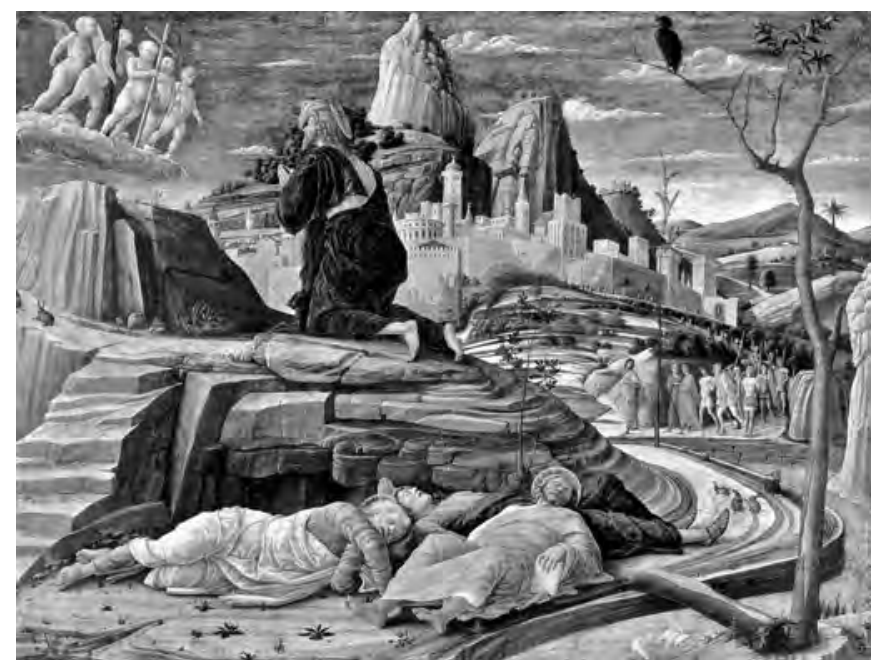

Volviendo a nuestro comentario, podemos considerar los Emblemas del holandés Teocritus à Ganda y su Emblemata Amatoria del siglo XVII donde el ave reposa sobre el pecho de un difunto para señalar que la llegada de la muerte es incierta ${ }^{6}$, así lo observamos en los Emblemas de Alciato (Lám. 2a). Con el mismo argumento se presenta en el Emblema XXIII de Camerarius, tomando como fuente el señalado de Alciato donde el búho reposa sobre un finado ${ }^{8}$. Virgilio precisa en la Eneida esta relación del ave con la muerte: por los tejados un búho solitario con fúnebre canto (360-362).

No extraña, por tanto, que el ave resuma en su sentido semántico el propósito de la pintura. La muerte llega de manera imprevista a cualquier edad. Brueghel lo explica disponiendo el cuervo en el lomo del caballo que arrastra el carro de la muerte y que lleva de manera inexcusable y sin previo aviso a un destino final poco deseado entre los humanos.

Jacob Cornelisz van Oostsanen, hacia el año 1528, realizó la pintura sobre Saúl y la bruja Endor, argumento que se relata en el primero libro de Samuel (I Samuel 28,5-25). Explica como la hechicera anunció a Saúl su muerte inmediata y así, el artista lo refleja mediante los búhos que se figuran en la silla de

6. HEINSIUS, Daniel (1580-1655), ("Theocritus Ganda"). Emblemata Amatoria. lam demum emendate. Amsterdam, Dirck Pietersz, 1608. Dispone la lechuza entre las lápidas y el búho sobre el cadáver.

7. ALCIATO, A., Emblemas. Lyon 1549. L.II., p. 169. Con el lema: El viejo enamorado de mujer moza.

8. CAMERARIUS, J., Symbolorum et Emblematum... Edición de Frankfurt 1654. Centuria III, Emblema XXIII). 


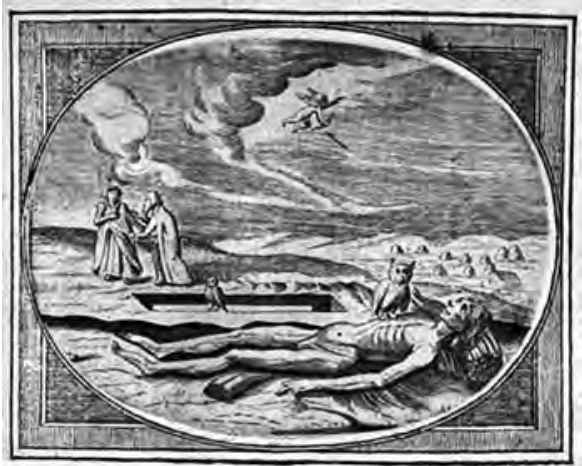

Lámina 2a. Heinsius,

Daniel (1580-1655),

("Theocritus Ganda").

Emblemata Amatoria.

Búho sobre el

cadáver.

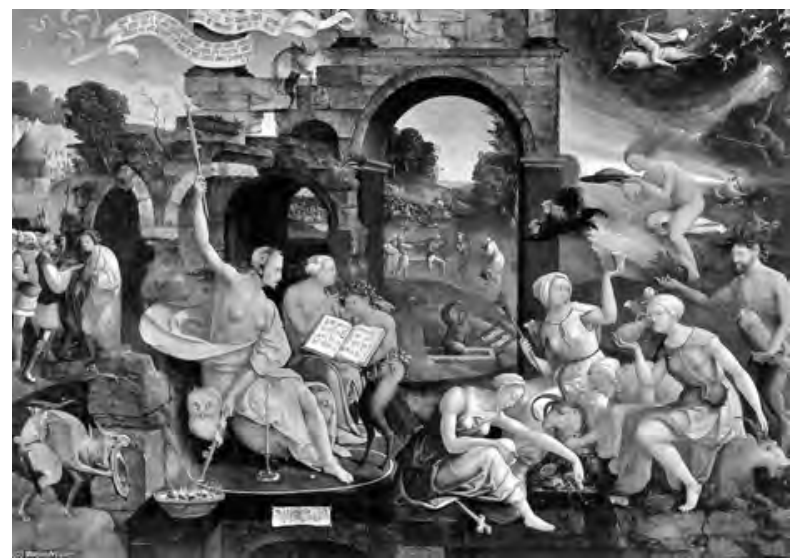

Lámina 2b. Jacob

Cornelisz van

Oostsanen. Saúl y

la bruja Endor

(Rijksmuseum,

Amsterdam).

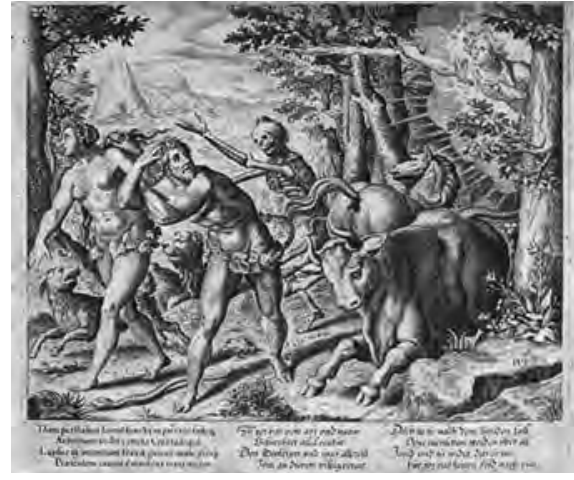

Lámina 2c. Domenicus Custos. Expulsión del paraíso y Ilegada de la muerte. Siglo XVI.

Lámina 2d. Cornelis van Haarlem. La caída de los primeros padres (Rijksmuseum, Amsterdam).

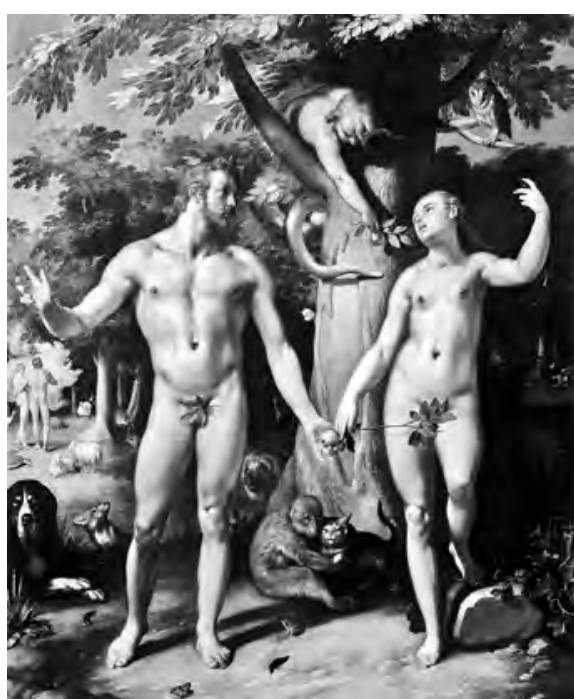

BROCAR, 38 (2014) 145-162 
la nigromante (Lám. 2b). Salvatore Rosa recurre a la disposición de ave nocturna en este mismo asunto argumental. Ambrosio Francken, a comienzos del siglo XVII, ofrece en sus estampas el búho, concretamente en la titulada las edades del hombre donde aparece el carro de la muerte y el tiempo que conducen a las Parcas atropellando a los humanos de toda edad, aspecto que se explica nuevamente por el ave nocturna.

En el pensamiento cristiano, con la caída de los primeros padres llegó la muerte a la humanidad, una muerte que vence a la vida de manera silenciosa. Así lo apreciamos en estampas de Hans Sebald Beham y, entre otros, en Étienne Delaune y en la lámina abierta por Domenico Custos (Lám. 2c). Con esta intencionalidad se recrea al búho en la pintura de Cornelis van Haarlem en su argumento sobre la Caída de Adán y Eva (1592) que se conserva en el Rijksmuseum de Amsterdam (Lám. 2d).

Salvatore Rosa, hacia 1650, presenta el búho en su Demócrito en Meditación. La lámina figura al anciano concentrado, meditando sobre la caducidad de la vida, se acompaña por los despojos de animales repartidos en el suelo como referencia a lo efímero de la vida y la llegada de la muerte sin aviso previo. La estampa del 1500 abierta por el monogramista MZ así lo expresa mediante una mujer que huye de los rayos donde aparece la inscripción DVCK DICH, "escóndete", razón por la que trata de ocultar el búho, expresando con ello el temor a la llegada de una muerte imprevista. Similar idea, figurada por el ave, la observamos en la estampa de Martin Baes de 1633 como ilustración en la edición de Carolo Musart titulada Adolescens academicus seu institutione Salomonis, donde nada pueden defender las armas, la muerte imprevista llega con furia y rapidez a modo de rayo, de ahí el búho (Lám. 3a).

En la zona inferior derecha de la pintura elaborada por Brueghel nos encontramos una pareja que, sumida en la música del laúd, ignora lo que sucede a sus compañeros de juego quienes, aterrados, observan la llegada de la muerte (Lám. 3b). Se trata de la juventud a quienes no perdona la parca. El laúd así lo expresa, remite al humor sanguíneo propio de esa edad donde lo sensual parece meta obligada como lo apreciamos en las estampas de Virgil Solis o en Mariettte, sin olvidar pinturas como la de Theodor van Thulden como su Alegoría del matrimonio donde la joven, con el laúd, se acompaña de Himeneo; también el instrumento músico se observa en el Jardín del Amor que compusiera Rubens y en tantas otras manifestaciones artísticas como en la serie citada de Ambrosio Francken.

Es la muerte victoriosa ante el amor sensual; así aparece en las estampas de Crispyn van de Passe donde Cupido lanza su flecha amorosa a la pareja de enamorados. Aquí, el simio expresa la sensualidad del noble caballero acompañado con el halcón y de la dama junto al perro. Un detalle Ilama la atención, se presenta otra vez de búho como clara referencia a la vanidad, a lo temporal, a lo efímero del amor humano, pues como se señala en la estampa, los placeres se 


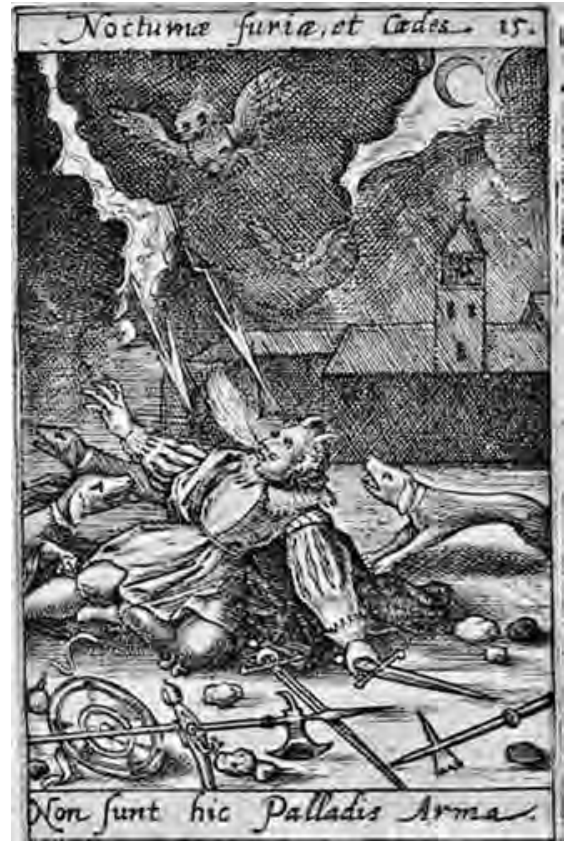

Lámina 3a. Martin Baes. Adolescens academicus seu institutione Salomonis, edición de Carolo Musart, 1633. El búho como expresión de la muerte imprevista.

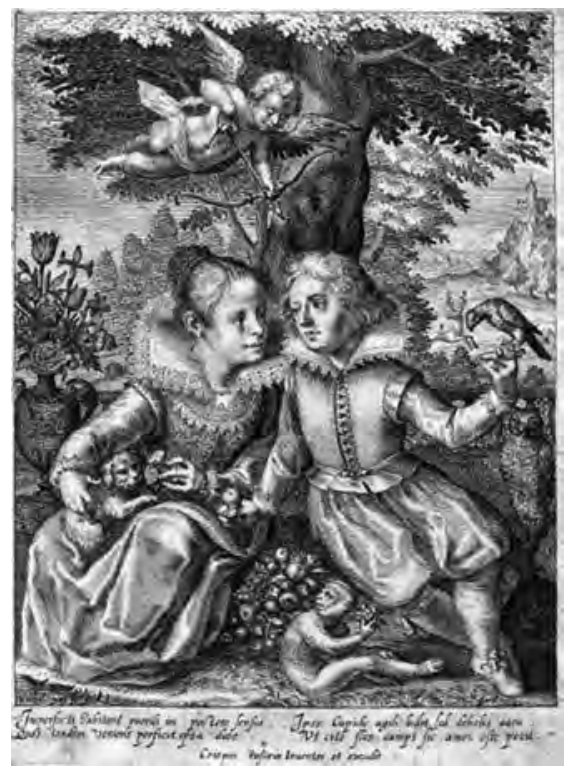

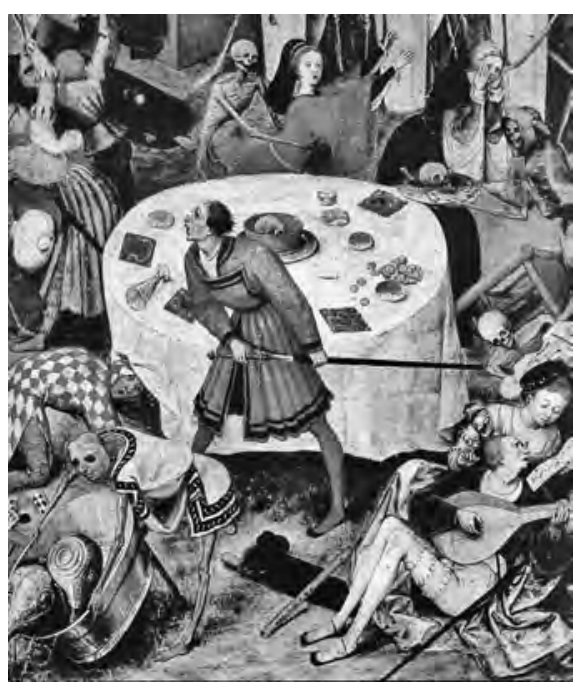

Lámina 3b. Pieter Brueghel. Triunfo de la Muerte. Llegada de la muerte con máscara (detalle).

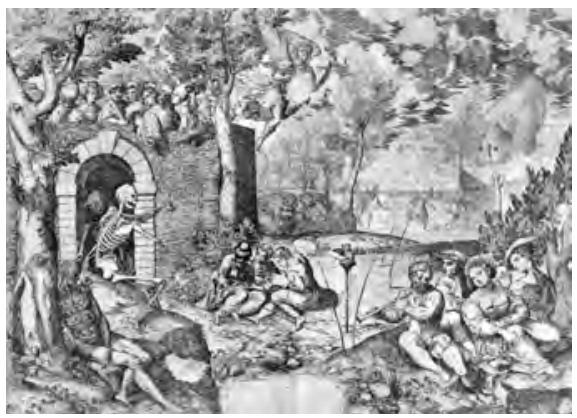

Lámina 3d. Giovanni Paolo Cimerlino.

La llegada de la muerte imprevista. 1560.

Lámina 3c. Cryspin van de Passe.

El amor efímero y el anuncio de la muerte. Siglo XVI. 
evaporan en un instante, como se marchitan las flores del campo (Lám. 3c). La lámina de 1560 abierta por Giovanni Paolo Cimerlino dispone a la muerte presentándose a un grupo de jóvenes centrados en el estudio y a otro en claro divertimento, curiosamente es el búho quien centra la composición precisando con ello que la muerte es imprevista para todos (Lám. 3d). Así lo apreciamos en el cobre abierto en 1470 por Baccio Baldini donde la muerte, tomando el manto de la doncella, se presenta ante una pareja que se recrea con la música; en la zona superior observamos nuevamente al búho que, en su figura, resume la intencionalidad señalada en la inscripción, llega siempre de manera imprevista (Lám. 4a).

La imagen que nos ofrece Jacob Cast es claramente explicativa sobre este argumento. Los amantes se disponen junto a Cupido, dos palomas unidas por sus picos refieren al amor sensual; el dios del amor acompañado de una antorcha se enfrenta a un esqueleto cuya única arma es un cráneo. A su lado una pala y una tumba abierta y, en el suelo, reposan cadáveres. Es la victoria de la muerte sobre el humano amor, de ahí el búho en la rama junto a la muerte, de ahí la dialéctica entre las palomas y el búho, pues remite a su victoria sobre la sensualidad, al triunfo de la muerte que nunca avisa en su llegada (Lám. 4b).

En la pintura de Brueghel, se disponen unas cartas de juego en el suelo, unos naipes que han caído tras la huída de los jóvenes ante el horror que produce la Ilegada del final en la vida. Es así que a lo sensual figurado por la música se une el juego. Ripa, toma ambos elementos, laúd y cartas, para remitir a la idea de escándalo y lo hace mediante un anciano que porta el mazo de cartas para significar que la alegría es propia de los jóvenes, pero no de los entrados en edad que aportan mal ejemplo, es decir, escándalo.

El placer, lo sensual como atracción en la vida lo apreciamos en la estampa de Urs Graf de 1511. En ella se da cita tanto el joven como el anciano, el laúd y los naipes. La doncella que centra la composición, toma el dinero del anciano para entregárselo al joven, a cambio le permite disponer la mano en su seno. En la zona inferior apreciamos el cráneo y con él se establece la secuencia moral, una filacteria que reza: Bedek das end das ist mein rot: Wan alle ding beschlüszt der todt: todo es podredumbre y no lleva a otro lugar sino a la muerte (Lám. 4c). El modelo fue seguido por Lucas de Leyden en su estampa sobre la cortesana y el anciano.

Así lo propone Brueghel en su pintura, precisando por imágenes que el placer, el mundo sensual tiene su final. Similar intención apreciamos en el Bosco y su Carro de Heno del año 1500 donde, sobre el árbol, se dispone un búho, la muerte imprevista, bajo las ramas los jóvenes se solazan con la música sobre el carro repleto de heno, de vacías vanidades.

Es la muerte quien se presenta a modo de transido en la pintura que comentamos donde un joven la observa aterrorizado $y$, agachado, trata de esconderse bajo la mesa. La muerte, el transido, vestida con bello manto, busca bajo el barreño y curiosamente, un detalle llama nuestra atención, porta una máscara. 


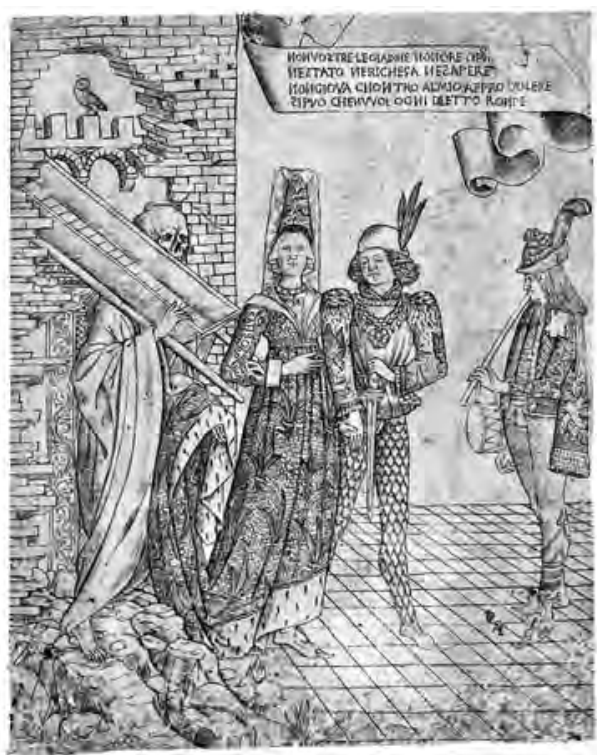

Lámina 4a. Baccio Baldini. La llegada de la muerte imprevista. 1470.

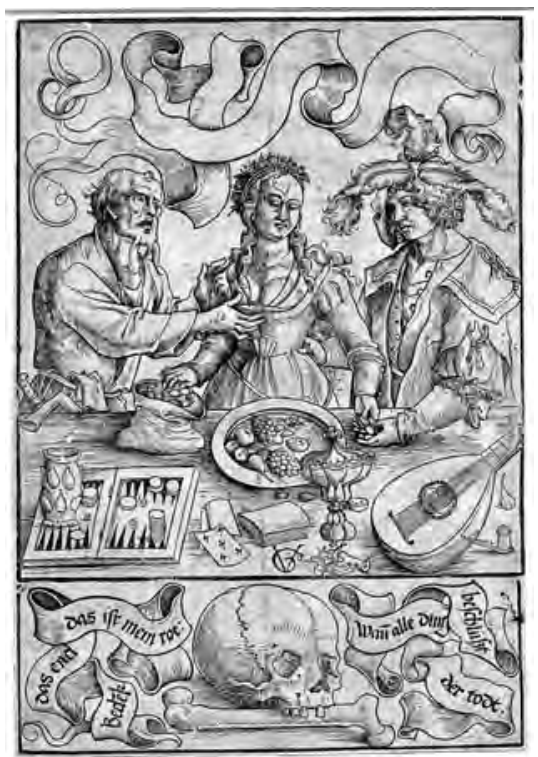

Lámina 4c. Urs Graf. Alegoría de los placeres mundanos. 1511.

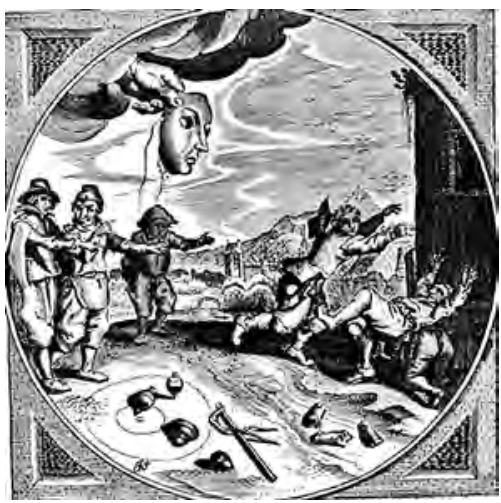

Lámina 4d. Jacob Cats. Proteus. Mors Larvae similes. 
Entre todas las figuraciones del esqueleto que pueblan por su abundancia la pintura, tan sólo en este caso la muerte se recrea con la máscara. Por ello, por su singularidad, comentaremos la razón de esta disposición iconográfica.

El origen de este planteamiento lo encontramos en Platón, en su diálogo sobre el alma conocido por el Fedón donde habla de la llegada de la muerte, una muerte que se aparece a modo de máscara, en latín larva, término que explica y entiende a modo de "duende". Ficino, en la Florencia del siglo XV y en su comentario a Platón lo traducirá por "larvae", es decir, fantasma. Un fantasma que puede atemorizar como a los niños una máscara, pero que no se debe temer por quien a dedicado su vida al conocimiento. Precisa Platón en su diálogo recogido en el citado Fedón (77e):

Queda demostrado, pues, lo que decís desde este momento incluso. No obstante, me parece que, tanto tú como Simmias, discutiríais con gusto esta cuestión con mayor detenimiento, y que teméis, como los niños, que sea verdad que el viento disipe el alma y la disuelva con su soplo mientras está saliendo del cuerpo, en especial cuando se muere no en un momento de calma, sino en un gran vendaval.

Cebes, entonces, le dijo sonriendo:

- Como si tuviéramos ese temor, intenta convencernos, oh Sócrates. O mejor dicho, no como si fuéramos nosotros quienes lo tienen, pues tal vez haya en nuestro interior un niño que sea quien sienta tales miedos. Intenta, pues, disuadirle de temer a la muerte como a la máscara (duende, fantasma, larva).

Sobre este temor, infundado en el hombre que dedica su vida al conocimiento, dice:

Los hombres ignoran que los verdaderos filósofos no trabajan durante su vida sino para prepararse a la muerte; y siendo esto así, sería ridículo que después de haber perseguido sin tregua este único fin, recelasen y temiesen, cuando se les presenta la muerte.

Pero el joven, en la pintura de Brueghel, tiene miedo a la máscara, al fantasmal duende que se presenta de manera imprevista y, por ello, huye, se esconde bajo la mesa. La recreación señalada por Platón queda recogida en el emblemista Cast, pues en el cuerpo figurado del emblema y con el mote Mors Larvae similis nos habla en este sentido: el temor a la muerte que aparece como una máscara, y lo hace siguiendo con claridad el texto señalado en el Fedón, es decir, mediante la máscara, la larva que asusta a los jóvenes y a los ignorantes ${ }^{9}$ (Lám. 4d).

9. CATS, Jacob. Proteus. Ed. 1658. Mors Larvae similes. 


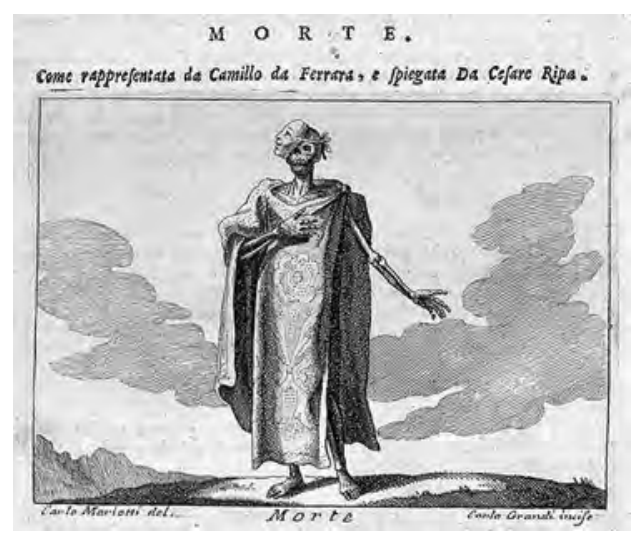

Lámina 5a. Ripa, C. Iconología. Morte.

Lámina 5b. Ghirlandaio, R. Máscara. Lema: sua cuique persona. Galería Uffizi. Florencia.

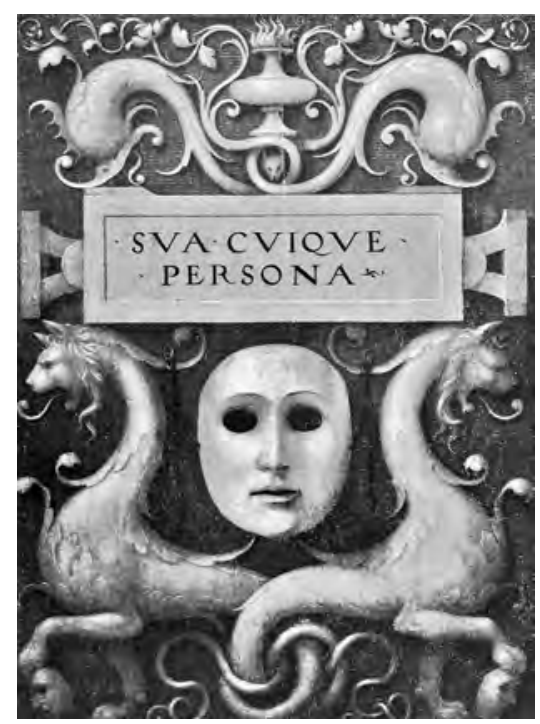

De igual manera, Cesare Ripa en la edición de su Iconología en el año 1593, fundamenta una de sus iconografías sobre la muerte mediante la máscara señalando una misma intencionalidad que vamos dando cuenta, la máscara como medio, como duende que llega a cada uno de manera distinta, a unos asusta, a otros conforta (Lám. 5a):

Camillo de Ferrara, Pintor excelente, representó a la muerte con toda su osamenta, sus músculos y sus nervios, ostensiblemente marcados... En la cabeza puso una delicada máscara de bellísimo color y fisonomía, pues la muerte no se muestra para todos la misma, sino que transformándose continuamente con sus mil caras agrada a unos, disgusta a otros, unos la desean, otros la huyen, siendo el fin de una prisión oscura para los ánimos generosos, mientras para otros es daño y necesidad...

Edgar Wind apunta uno de los jeroglíficos de Horapolo en este sentido donde dos ojos se disponen sobre la máscara. Nos dice que la imagen representa a los dioses Manes, ejemplo de las tinieblas y lo propiamente infernal. En este sentido conviene apuntar que el jeroglífico señalado no se encuentra en la antigua edición de los Hieroglyphica, más bien se corresponde a uno de los añadidos que hiciera Giulio Franceschini en su edición de Roma en 1597 con 184 estampas $^{10}$.

10. Hieroglyphica de Horapolo. Edición Giulio Franceschini. Roma 1597. 


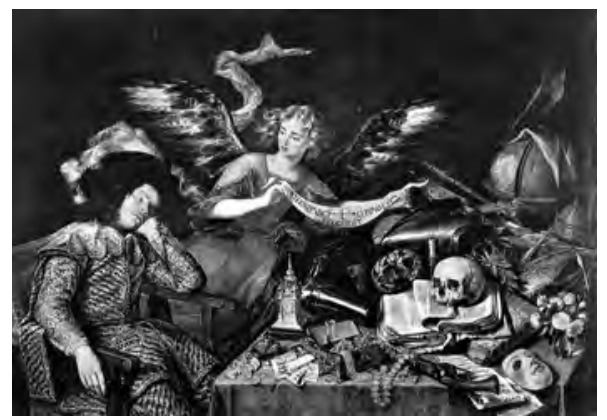

Lámina 6a. Antonio Pereda. El sueño del caballero. Real Academia de San Fernando (c. 1660).

Lámina 6b. Michel Coxie I. San Jerónimo y su visión del fin del mundo. Siglo XVI.

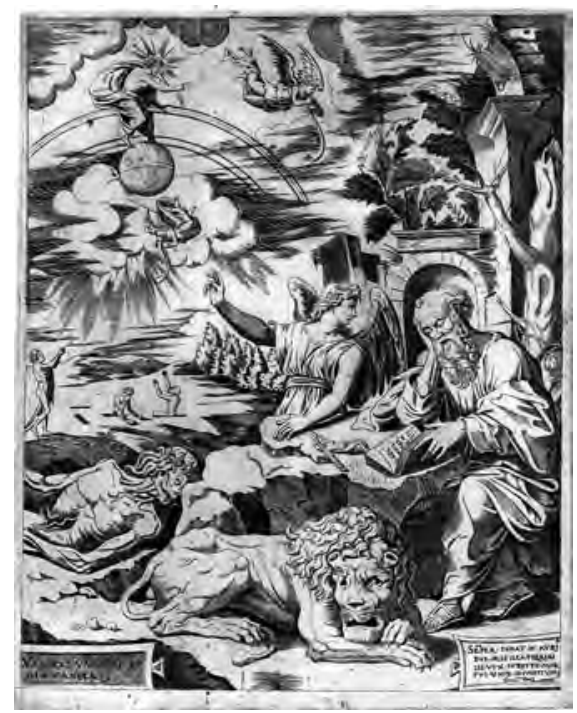

El hijo de Domenico Ghirlandaio, Ridolfo (1483-1561), afamado pintor en el Renacimiento, elaboró un óleo sobre madera hacia el año 1510 conservado en la actualidad en Galería florentina de los Uffizi. La pintura nos presenta a una joven mujer que lleva un libro en su mano con la inscripción "IHS" por lo que se ha titulado el retrato como Joven monja. Lo curioso es que el retrato incluye otra pintura diseñada para cubrirlo; un falso panel pintado con relieves grotescos que rodea una máscara bajo el mote: Sua Cuique Persona, que se ha traducido como: "a cada uno su máscara". Bien puede entenderse en el sentido que cada persona oculta su verdadera identidad o, quizá, en relación con lo que llevamos dicho, que cada uno tiene su propio duende, sus propios miedos o fantasmas. El mote latino parece provenir de Quintiliano en su Institución Oratoria (V,13), aunque también se encuentra en Séneca (De Beneficiis II,17) (Lám. 5b).

Así, Giacinto Gimignani en el siglo XVII nos ofrece un dibujo recreando a un anciano sentado; la muerte se figura por el esqueleto junto a un niño que porta una máscara, similares elementos a los descritos por el emblemista Cast en referencia a la muerte como duende o fantasma que asusta en su presencia.

No extraña, en consecuencia, que Antonio de Pereda (1611-1678), en su Sueño del caballero de hacia el 1660 y conservado en la Real Academia de san Fernando, recree a un joven en postura melancólica sumido en el sueño; sobre la mesa reposan todos los atributos comunes en la época barroca como imagen de la vanitas, la vela apagada expresa el final de la vida como lo apreciamos en Valdés Leal y en otros artistas como Saint-André. También se dan cita dos cráneos y una máscara (Lám. 6a). La composición, ofrece al caballero en postura melancólica, el ángel indicando, recuerda la estampa de Michel Coxie I sobre 
san Jerónimo y su visión del Juicio Final donde el real transido con serpientes en su corona expresa con claridad la misma intención de vanitas que nos ofrece Pereda, y así se señala en la zona inferior de la lámina: Vanitas Vanitat et omnia Vanitas (Ecl. 1,2) (Lám. 6b). La iconografía está en clara dependencia de la composición de Erhard Schön que realizara en 1532 donde apreciamos las serpientes rodeando la corona de la muerte.

En el lienzo, como hemos señalado, está presente la máscara junto al cráneo como anunció del final de la vida, pues como reza el mote que acompaña al ángel: la muerte llega rápidamente. La máscara en esta pintura se ha considerado como referencia al fraude engañoso de las vanidades en la vida, de ahí todas las figuraciones que observamos en la composición; también como atributo de la musa Talía, es decir, como un teatro que supone el discurrir por la vida. No obstante, al disponerse junto a los cráneos bien puede fundamentar el sentido que comentamos y así ha sido muy considerado en el arte, la figuración del duende o fantasma que, a modo de máscara, se aparece en el último sueño que da paso a la noche final, pues como reza el escrito en la filacteria, muy similar en su intención a la pintura de Valdés Leal, in ictu oculi, en un abrir y cerrar de ojos, la muerte:

Aeterne pungit, cito volat et occidit

Eternamente hiere, vuela veloz y mata 